\title{
Conceived spiritualities fostered by the multiple references regarding the communication of the 'message' about Jesus as the Son of God in 1 John
}

\begin{abstract}
Author:
Dirk G. van der Merwe ${ }^{1}$ (1)

Affiliation:

${ }^{1}$ Faculty of Theology, North-West University,

South Africa

Corresponding author: Dirk van der Merwe, dirkvdm7@gmail.com

Dates:

Received: 08 June 2018 Accepted: 17 July 2018

Published: 19 Nov. 2018

How to cite this article: Van der Merwe, D.G., 2018, 'Conceived spiritualities fostered by the multiple references regarding the communication of the 'message' about Jesus as the Son of God in 1 John', HTS Teologiese Studies/ Theological Studies 74(3), a5143. https://doi.org/ $10.4102 /$ hts.v74i3.5143

\section{Copyright:}

(c) 2018. The Authors. Licensee: AOSIS. This work is licensed under the Creative Commons Attribution License.
\end{abstract}

Read online:

$\begin{array}{ll}\text { 口ifitis } & \begin{array}{l}\text { Scan this QR } \\ \text { code with your } \\ \text { smart phone or } \\ \text { mobile device } \\ \text { to read online. }\end{array}\end{array}$

The schism referred to in 1 John 2:18 had already taken place within the Johannine community, with specific reference to the divisions between members, about the identity of Jesus Christ. The author nonetheless uses different semantically related verbs for communicating the 'message' $(1: 5 ; 3: 11)$ about Jesus' identity, each one with a particular nuance: through 'speech,

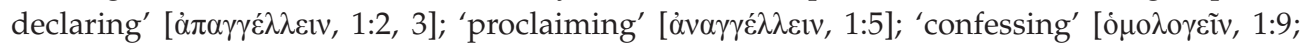

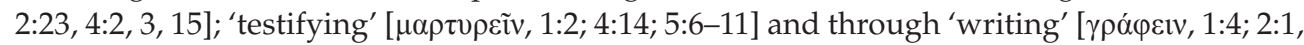
$7,8,12,13(2 x), 14(3 x), 21,26 ; 5: 13]$. In the last chapter of 1 John (1 Jn 5:5-12), the author's testimony (in writing) that there is eternal life in Jesus Christ who is the Son of God culminates when he incorporates the fundamental testimonies of the Father, the Spirit and the water and blood to endorse this. The intention of this research is to determine conceivable spiritual experiences fostered among those early Christians when this message about Jesus as the Son of God, the Christ, was communicated to them through these activities (declaring, proclaiming, confessing, testifying) and confirmed via the testimonies of the Father, the Spirit and the water and blood.

\section{Introduction}

Devotion to Jesus after his death and resurrection quickly resulted in an 'unparalleled innovation, a "mutation" or new variant form of exclusive monotheism' (Hurtado 2003:64). Jesus Christ was associated and included with God in the devotional program of Christian groups. The most conceivable factor to make sense of this, according to Hurtado (2003:65), was the effect of 'powerful religious experiences in early Christian circles'. ${ }^{1}$ Such experiences struck the recipients as bearing revelatory validity and force. This was sufficient to demand a reconfiguration of the monotheistic practice (Hurtado 2003:65). This is exactly what is described in 1 John.

Unfortunately, the religious experiences labelled and described in the early Christian sources did not really receive recognition in scholarly research until the eighth decade of the previous century. ${ }^{2}$ The focus of New Testament research was predominantly on New Testament support or challenge of Christian beliefs. Actually, little attention was paid 'to the nature and importance of the religious experiences attested' (Hurtado 2003:65; also Johnson 1998:2). The publications of Dunn (1975) ${ }^{3}$ and Gunkel (1979) on religious experiences contributed to growing interests in religious experiences in the early Christian Church. ${ }^{4}$ Hurtado (2003:66) is of the opinion that in order to understand early Christianity adequately, significant attention should be paid to the religious experiences of early Christians. Those experiences constitute a major part of the early Christian character.

\footnotetext{
According to Johnson (1993:4), an 'impressive amount of religious experience' can be found in the New Testament writings. For him the New Testament differs from other ancient religious texts remarkably because of its high frequency of discourse about experience. The texts of the New Testament communicate numerous encountering statements and claims about what the authors and audience The texts of the New Testament communicate numerous encountering statements and claims about what the authors and audience
(hearers) had already experienced or were still experiencing (1993:5). See also Johnson (1993:5-8) in his footnotes 3-28. Dunn $(1975: 195)$ points out that the early Christian believers claimed to experience both God and Jesus. Luke reports in Acts that Pau experiences Jesus in various visions (18:9; 22:17f.; etc.). Paul declares in Galatians (2:20) that Christ lives in him. Similarly, according to the Gospel of John, Jesus promises to realise his dwelling in his disciples after his glorification (Jn 14:18-23). Some experiences are also ascribed specifically to the Spirit (e.g. the glossolalia of Acts, the charismata of I Cor 12-14).

2.Schleiermacher (1830) has already conceptualised 'religious experience' during the 18th century in his publication Die Christliche Glaube [The Christian Faith]. Here we have to distinguish clearly between 'religious experience', 'Christian experience' and 'early Christian experience'. The above discussion is about 'early Christian experience'. All this is also confirmed by Dole (2016:44).

3.Jesus and the Spirit: A Study of the Religious and Charismatic Experience of Jesus and the First Christians as Reflected in the New Testament.

4.Publications on religious experiences prior to Dunn $(1970,1975)$ were Gunkel (1979 [1888]); Clark et al. (1973); and Stark (1965:97-116). After Dunn came Fee (1994): Johnson (1993) and Hurtado (2003). See Stark (1991) for a critique of religious experiences that often occur in social-scientific circles. At the end of the previous century, Johnson (1993:12-26; also Hurtado 2000:184) referred to religious experience as a 'missing dimension' in New Testament scholarship. Czachesz (2015:6) regards the beginning of the 21st century as the turning point for new interest regarding religious experience. This interest was attended to in biblical studies (see also Batluck 2011; Craffert 2008; Flannery, Shantz \& Werline 2008; Hurtado 2000; Pilch 1996, 2011; Räisänen 1999, 2000; Shantz \& Werline 2012; Theissen 2007, 2013).
} 
Gunkel (1979:100) interprets 'Paul's utterances in light of his own experience'. It was not a matter of reading or even just hearing. For Gunkel (1979), Paul's:
... experience of the power and depth of his spiritual inspiration ... was driven by the power of the Spirit of Christ. Spirit is the divine, supernatural power, and when Paul asserts that the entire conduct of the Christian is an activity of God's Spirit, he is saying that there is a power manifest in the Christian life which is divine, that is, absolutely supernatural. (p. 100)

For Paul, 'this power is "experienced" (endured: $\pi \alpha \theta \varepsilon i v)$ ), as are its activities (Gl 3:4)' (1979:93). Dunn (1975:4) warned against 'discounting the creative force of religious experience'. For him, we have to acknowledge Paul's creative power of his own religious experience (1975:4). Almond (1982:166-67) emphasised that powerful religious experiences could have caused the 'creative transformation of a religious tradition'. For him, such experiences had the potential to generate 'new interpretations of the tradition' (1982:168). Thus, the early Christian documents designate that after Jesus' crucifixion a significant reformulation of his adherents' faith was coupled to their religious experiences (Hurtado 2003:71). ${ }^{5}$

According to Hurtado, the experiences of the resurrected Jesus in early Christianity had an extraordinarily exalted place for Christians in their devotional lives. The inherited commitment to monotheism that was characteristic of early Christianity helped to shape this devotion to Christ. Hurtado termed this direction 'binitarian', rather than a direction towards an apotheosis of Jesus as a new deity. This view of Jesus had to be communicated in a Christian community where differences occurred with regard to Jesus' identity. This then resulted in an innovative devotional configuration. For these early Christians, their inclusion of their cultic devotion of Christ was the constitution of 'a new variant form of exclusivist monotheism’ (Hurtado 2003:78).

The experiences of Jesus have led to the following convictions by the author about Jesus' identity, as noted in 1 John: (1) that a unique relationship exists between the Father and his Son Jesus Christ (2:22-24; 5:9, 10); (2) that the Son of God has been incarnated in the person of Jesus to give believers understanding of God's love and to experience this divine being $(4: 9,10)$; $(3)$ that the Son of God was revealed for this purpose, to destroy the works of the devil; (4) that the Father and Son are experienced through fellowship when the audience believe the testimony of the author about the incarnation of the Son (1:3); (5) that Jesus has been exalted to a unique heavenly status, presiding over the divine redemptive program - for the sinner, he acts as an advocate on behalf of the sinner by the Father (2:1) (Van der Merwe 2005:444-48); and (6) that Jesus will also come again in eschatological glory (1 Jn $2: 28 ; 3: 2 ; 4: 17)$.

The author uses different Greek verbs to communicate in the past and present (time of writing), in the Johannine community,

5.Jantzen (1989:302) refers to William James, who held the opinion that religious experience is central to religion. the 'message' concerning Jesus Christ as the Son of God. The use of these words probably reflects on what happened in the community prior and probably also during the writing of 1 John. The enquiry nonetheless is, 'what were the conceivable lived experiences ${ }^{6}$ fostered by the author's references of his communication ${ }^{7}$ of the Christian message $(1: 5 ; 3: 11)$ concerning Jesus Christ through both his speech and writing?' In addition to this, a second question can be raised: 'what were the conceived lived experiences fostered by the author's incorporation of the testimonies of the Father, the Spirit and the water and blood (5:5-13) in his defence that Jesus is the Son of God?'

A reply to these questions requires this essay to start looking briefly into the socio-historical circumstances of the community where the messiahship (2:22) and sonship (2:23) of Jesus were disputed. This will create the environment for the understanding of the rest of the essay. Then a survey of the various semantically related Greek verbs, used by the author in communicating the message, will be scrutinised in their immediate literary contexts.

\section{The socio-historical circumstances in the community}

1 John has a strong polemical tone and reflects a major historical crisis that powerfully affected Christianity in the Johannine community in which, and for which, 1 John was originally written (see Lieu 1997:5-6, 13-16, 19; Painter 2002:84-86; also Van der Merwe 2009:231-261). This polemical tone, evident in dialectic language in $1 \mathrm{John}$, undoubtedly characterises the strong declarations about Jesus. This reflects the effect of the crisis, which involved polemics about Jesus. 'The Johannine Christians then probably sharpened and refined their views of Jesus in response to opposition and controversy' (Hurtado 2003:350).

Throughout 1 John, the author describes the assertions of the deceivers. ${ }^{8}$ By studying their claims, a possible construction of it is possible, consisting of true divine knowledge and the outlines of their doctrine and ethics. In this research, I will only focus on the Christological issue due to the acute occurrence of this issue in 1 John 5 and its applicability to the theme of this research.

The confessional formulas that the author brought against them in 1 and 2 John (1 Jn 2:22; 4:2, 3, 15; 5:1, 5, 6, 10, 13; 2 Jn 7) help to understand their basic Christological beliefs. ${ }^{9}$

6. In this discourse, early Christian spirituality, influenced by Waaijman (2002:312) and Schneiders (2000:254), is understood as the 'lived experience' of the divine, resonating with the faith and conduct of the believer.

7.Verbal communication of the message makes the incarnated 'Word' experiential.

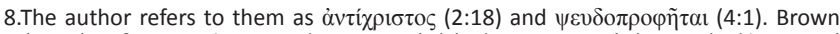
(1995) refers to them as 'opponents' (x), 'secessionists' $(69,70)$, 'deceivers' (358-359), 'adversaries' (415) and 'propogandists (429). Painter (2002:84) refers to them as 'schismatics' and 'propogandists'.

9.First John emphasises certain doctrines applied by the deceivers. This is necessary to judge whether they are true or false Christians. One symptomatic phrase that

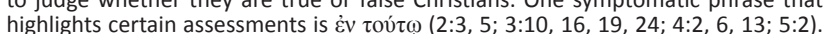
Another configuration is the if-clause: غ́áv (1:6-7, 8ff. 2:3, 15, 24,29;3:21; 4:12, 20 ; Another configuration is the if-clause: $\varepsilon \alpha v(1: 6-7,8 f f . ; 2: 3,15,24,29 ; 3: 21 ; 4: 12,20$;
$5: 15)$. The subjunctive mood of the verb is also used in these if-clauses. In contrast, in 2:19 the author uses the subordinating conditional $\varepsilon \dot{i}$ [if] and the indicative mood 
The historical Christological focus in 1 John is the intersection of the human and divine natures of Jesus. This intersection is defined according to how the author tends to think his audience believe and confess: (1) Jesus is the 'word of life' who was revealed $(1: 2,3)$; (2) 'Jesus is the Christ' (2:22; 5:1); (3) 'Jesus is the Son of God' (4:15; 5:5); (4) 'Jesus Christ has [is] come in the flesh' (4:1-3; 2 Jn 7); (5) 'the one who came by water and blood, Jesus Christ' (1 Jn 1:7; 2:1-2; 4:2, 9, 10, 14 [15]; 5:6; see also 3:16); (6) that 'the Father has sent his Son as the Savior of the world' $(4: 9,10,14)$; and (7) that he will

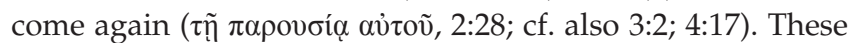
seven creedal formulas reflect the basic Christological doctrines of the opponents. They are further demonstrable

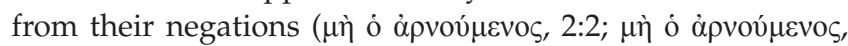

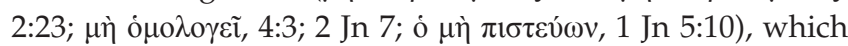
occur in all of these references (Van der Merwe 2009:231-261). It is against this background that the lived experiences fostered in witnessing should be understood.

\section{Multiple verbs used by the author to refer to his communication of the message about Jesus}

The author uses different semantically related Greek verbs to strengthen the truth and reliability of his communication of the message $(1: 5 ; 3: 11)$ concerning Jesus Christ as the Son of God so that the audience could come to faith or strengthen their faith in him through speech, 'declaring' [ả $\alpha \alpha \gamma \gamma \varepsilon \dot{\lambda} \lambda \lambda \varepsilon \mathrm{v}$,

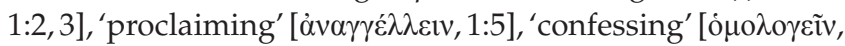

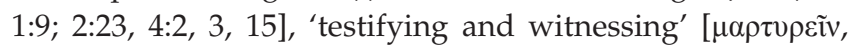
$1: 2 ; 4: 14 ; 5: 6-11] .{ }^{10}$. Lived experiences were fostered via the author's communication through references to both speech ${ }^{11}$ and writing of the Christian message concerning Jesus Christ as Son of God. ${ }^{12}$ Each of these verbs, referring to the communication of the message, will be discussed concisely in connection with their usage in 1 John in relation with the message and lived experiences (spiritualities) ${ }^{13}$ attached to

\section{(footnote 9 continues...)}

in a contrary-to-fact condition, and in 3:17 he uses ôc $\delta$ ' ö $\mathrm{v}$ and the subjunctive in the conditional relative clause. According to Filson $(1969: 264, n$. 7), all these passages involve a condition. This variety of clauses indicates how serious the author was in assessing Christian thoughts and actions. According to Byrskog (2009:43), a testimony in antiquity (also today) was always presented from a particular point of view. The witnesses were influenced by their environment: belonging to a 'certain clan or family or an ethnic or religious group'. Observation then comprises interpretation from the interpreter's own standpoint.

10.According to Philo (Leg. All. III, 120), translated in Yonge (1995), well-approved language has two supreme virtues, namely, distinctness and truth, ... 'For it is language which has in the first place enabled one man to make affairs plain and language which has in the fre plow evident to his nighour intimation of that emphasises it with a repetition, 'judicious language, [which] is invested with two virtues perspicuity and truth'.

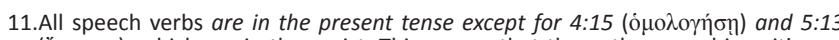
$(\varepsilon / \gamma \rho \alpha \alpha)$, which are in the aorist. This proves that the author sees his writing as declaring, proclaiming, testifying and confessing. Thus, the references to various kinds of communication complement the writing of the message.

12.The repetition of semantically related words, as a figure of style in the author's writing, also occurs in the author's use of the following semantically related vocabulary, where the author uses different words referring to related activities or states: He refers to 'that our joy may be complete' [ $\pi \varepsilon \pi \lambda \eta p \omega \mu \varepsilon ́ v \eta ; 1: 4]$ and to 'his

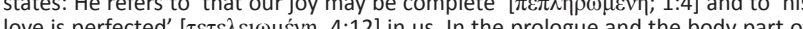
the epistle, he refers to both the seeing [ó ó́ $\omega, 1: 1,2,3]$ of and looking [ $\theta \varepsilon \alpha \alpha_{0} \mu \alpha$ $1: 1 ; 4: 14]$ at Jesus.

13.Kees Waaijman (2002:312) defines spirituality as 'the divine-human relational process of transformation'. This brief definition of Waaijman's can be divided into: the 'divine-human relationship' and a 'relationship of transformation'. With his each one. At any moment, the audience must bear in mind the tense situation in the community. Everywhere the author refers to his communication of the message, as well as the potential confession of any person, Jesus has been referred to.

From this analysis, two deductions can be made: firstly, the author wants to exemplify his verbal communication concerning the character and identity of Jesus. Through his writing, he wants to declare, confess, proclaim and testify that Jesus is the Christ, the incarnated Son of God. Secondly, his references to his writing also have idiosyncrasies through which lived experiences are fostered in order to affect his audience. This is a topic on its own and is discussed in another essay. ${ }^{14}$ The group of verbs, referring to the verbal communication of the author, will now be discussed.

\section{Investigation of the verbs the author uses to communicate the message}

The literary text is written with a specific intention of message and specificity of wording and figures of style so that it can evoke truthfulness (faith), convictions (lived experiences) and specific activities (obedience) within the audience. This research will focus on the meaning of the selected and specific located verbs the author uses in communicating the message about the character and identity of Jesus.

Words only have meaning in contexts..$^{15}$ Lexical meanings refer to possibilities of meaning words can have and have been used for. This investigation will start with consulting different kinds of dictionaries as a point of departure to determine these possibilities: the lexicons of Danker (2000) and Zodhiates (2000) as well as the semantic dictionary of Louw and Nida (1996). The theological dictionaries of Brown (1995) and Kittel (1978-1981) will also be used where necessary. The decisive factor in the end will be to determine the author's reason for using a particular verb for his reference for communicating the message. This again will help to determine the conceivable lived experiences fostered by the text. The immediate linguistic and broader literary contexts will facilitate this process of understanding while also considering the theological construct the author had in mind.

$\grave{\alpha} \pi \boldsymbol{\alpha} \gamma \gamma \varepsilon \dot{\varepsilon} \lambda \lambda \boldsymbol{\varepsilon} \mathbf{v}$ [to declare]: This verb was used twice $(1: 2,3)$ in the prologue: 'this life was revealed, and we have seen it and testify to it, and declare to you the eternal life that was with the Father and was revealed to us $-{ }^{3}$ we declare to you what we have seen and heard so that you also may have fellowship

definition of spirituality Waaijman lays a hand on the core of human existence, explicitly the relationship between God and the believer (cf. Van der Merwe 2017:1). This essay focuses on the conceivable fostered 'lived experiences' of the divine in the text of 1 John, when the Johannine Christians have read or heard the author's references to his communication of the message about Jesus' character and identity.

14.See Van der Merwe (2018), 'The author of 1 John uses the multiple references to his "writing" as a mechanism to establish affects and effects'.

15.See Köstenberger (2011), Invitation to Biblical Interpretation: Exploring the Hermeneutical Triad of History, Literature, and Theology. The section titled 'The socio-historical circumstances in the community' has already contextualised the circumstances and environment in which these texts have to be interpreted. 
with us; and truly our fellowship is with the Father and with his Son Jesus Christ' (New Revised Standard Version, NRSV).

Westcott made a valuable contribution in his distinction between the meanings of the verbs $\dot{\alpha} \pi \alpha \gamma \gamma \varepsilon \dot{\varepsilon} \lambda \dot{\varepsilon} \omega v$ and $\dot{\alpha} v \alpha \gamma \gamma \varepsilon \dot{\varepsilon} \lambda \lambda \varepsilon i v$. In his explanation, he started to refer to the verb $\dot{\alpha} \gamma \gamma \varepsilon \dot{\varepsilon} \lambda \lambda \varepsilon ı v$ [to bring tidings], ${ }^{16}$ from which they derive their fundamental meaning. The derivative verb $\alpha \dot{\alpha} \alpha \gamma \gamma \varepsilon \dot{\varepsilon} \lambda \lambda \varepsilon v v$ [to announce] conveys 'a distinct reference to the source or place from which the message comes' (Westcott 1902:15). Another derivative verb, $\alpha v \alpha \gamma \gamma \varepsilon \dot{\lambda} \lambda \lambda \varepsilon v$ [to report], also carries 'the additional idea of bringing the tidings up to or back to the person receiving them' (Westcott 1902:15). Important and to verify this distinction, Westcott points out that this verb

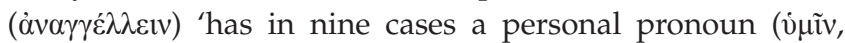
$\dot{\eta} \mu \mathrm{i} v)$ after it, and in the two remaining places where it occurs (Ac 15:4; 19:18) the persons to whom the announcement is made are placed in clear prominence' (1902:15). This then implies that in the case of $\alpha \pi \alpha \gamma \gamma \varepsilon \dot{\varepsilon} \lambda \lambda \varepsilon v v$, the origin is most prominent, and in the case of $\alpha \dot{\alpha} \alpha \gamma \gamma \varepsilon \dot{\varepsilon} \lambda \varepsilon \varepsilon v$, the recipient.

Danker (2000:95) defines $\dot{\alpha} \pi \alpha \gamma \gamma \varepsilon \dot{\lambda} \lambda \varepsilon \varepsilon \mathrm{v}$ as 'to give an account of someth[ing], report (back), announce, tell ... to make someth [ing] known publicly, proclaim (of someth[ing] in the present or fut[ure])'. For Louw and Nida (1996:33.198), it denotes, 'to announce or inform with possible focus upon the source of information - "to tell, to inform"; to announce what must be done - "to order, to command"'. According to Zodhiates (2000:517), it can be translated as, 'to bring a message from any person or place: (1) To relate, inform, tell what has occurred; (2) To announce, make known, declare, tell what is done or to be done; (3) To bring back word from anyone, report'.

The resemblance of definition between these three dictionaries is that $\dot{\alpha} \pi \alpha \gamma \gamma \varepsilon \dot{\varepsilon} \lambda \lambda \varepsilon v v$ gives account of something that happened in the past, what has occurred. The focal point is the source of information. The NRSV translates it as 'declare' $(1: 2,3)$. The author declares what was revealed to them, what they have seen (1:2); what they have seen, heard and touched (1:3). Thus, the origin of the message was important and in the context of the deceivers in 1 John to speak in particular the truth.

This verb and its semantically related derivatives are used in the Fourth Gospel to describe what both Jesus (4:25) and the Paraclete (16:25) will reveal in future. The Johannine background of this verb sanctions the author to claim the continuity of his own proclamation with the revelatory work of both Jesus and the Paraclete. The present tense usage of the verb implies that the author is proclaiming these things as he was writing. By using this verb, the author created the impression that he is busy making known to every audience 'information of extraordinary value' that was revealed in the past (Thomas 2006:68) and now by him.

In the consecutive verse 1:3, again the author uses the same verb, $\dot{\alpha} \pi \alpha \gamma \gamma \dot{\varepsilon} \lambda \lambda \varepsilon \mathrm{v} v$ [declaring]. Such repetition draws the attention of the audience, so as not to miss the emphasis the 16.This verb occurs only in John $20: 18$. author places upon his facts of communication of Jesus the Son of God. Now in 1:3, after two full verses, the author

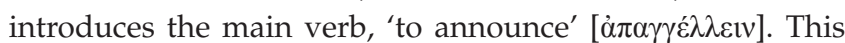
delay of the main verb created tension and an expectancy within the audience; that which was seen and heard

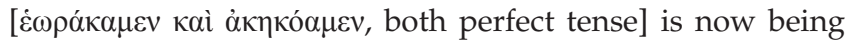
declared by the author. The purpose of the declaration [iv $\alpha$ ] is that the audience may experience fellowship with the author in sharing and participating or experiencing with him (and the tradition) what he communicated to them in 1:1-3 (what they have seen and heard). Through faith the audience will also see and hear the Son of God (the source of revelation). As a result of this experience, they together with the author will then corporately have fellowship (experience) with the Father and his Son Jesus Christ. The noun 'fellowship'

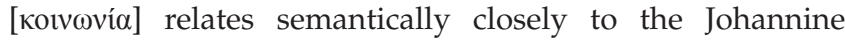
understanding of 'abiding', 'being in', 'being one' (see Jn 15:14-7; 17:21-23) (Thomas 2006:69-70):

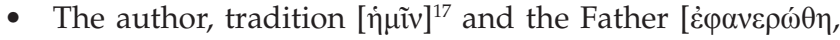
passive, aorist $]^{18}$ are the sources of this message. By using the verb $\dot{\alpha} \pi \alpha \gamma \gamma \varepsilon \dot{\varepsilon} \lambda \lambda \varepsilon v$ [to declare] in combination with the verbs 'reveal', 'seen' $(2 x)$, 'heard' and 'touched', the author focuses the attention on Jesus' existence and his reality of being the eternal life, the Son of God, that was experienced in a human body. He was the source of God's

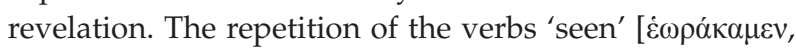

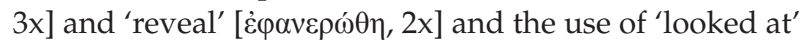
[ $\dot{\varepsilon} \theta \varepsilon \alpha \sigma \alpha \dot{\mu} \mu \theta \alpha]$ stressed the reality of the incarnated Son and also probably the author's excitement.

- The author's use of the first person plural ( $\dot{\alpha} \pi \alpha \gamma \gamma \dot{\varepsilon} \lambda \lambda \mathrm{o} \mu \varepsilon v$, 1:3) is to stress both his connection with the tradition (origin and sources) as well as to emphasise the continuity of the declaration of the message of Jesus by himself.

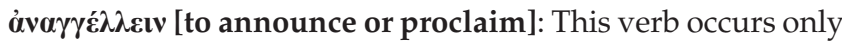
once in 1 John (1:5), 'This is the message we have heard from him and proclaim to you, that God is light and in him there is no darkness at all' (NRSV). With $\alpha v \alpha \gamma \gamma \varepsilon \dot{ } \lambda \lambda \varepsilon ı v$, opposite to $\dot{\alpha} \pi \alpha \gamma \gamma \varepsilon \dot{\varepsilon} \lambda \lambda \varepsilon v v$, the recipient is the focus in mind, although the acts remain the same (Westcott 1902:15).

Danker (2000:59) defines this verb as, 'to carry back information, to report; to provide information, disclose, announce, proclaim, teach'. For Zodhiates (2000:312) it can be translated with, 'to announce, make known, declare, tell of things done, events; of the Christian doctrine, to declare, show forth, teach'. Louw and Nida (1996:I, 410) describe it as 'to provide information, with the possible implication of considerable detail - "to announce, to inform, to tell"'.19

The NRSV correctly translates $\dot{\alpha} v \alpha \gamma \gamma \varepsilon \dot{\lambda} \lambda \lambda \varepsilon ı v$ as 'to announce' or 'to proclaim' (see also Smalley 1989:19 for a thorough discussion). From the immediate literary context, the

17.The author uses the personal pronoun (first, plural) to include the tradition with whom he has experienced (seen, heard and touched) Jesus.

18.The divine passive mode has been used to involve the divine in the revelation of Jesus.

19.Friberg, Friberg and Miller (2000:48) define it as follows: '(1) as carrying back news of happenings report, inform (AC 14.27); (2) generally announce, proclaim, openly declare (AC 19.18)'. 
announcement becomes more personal for the audience. It concerns 'what one has to tell another' (Haas, de Jonge \& Swellengrebel 1994:22). The communication is about what the author has heard from Jesus about God. The use of

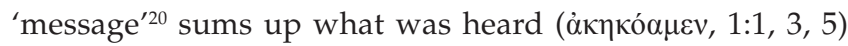
and announced ( $\alpha \dot{ } v \alpha \gamma \varepsilon \dot{\varepsilon} \lambda \lambda \varepsilon v, 1: 5)$. The focus is on the content of the message that has to be communicated to the audience.

By using this particular verb in the plural, the author again claims to stand in line with the proclamation of the Paraclete, who is the continuation of the proclamation of Jesus..$^{21}$ In the Fourth Gospel, this verb ( $\alpha v \alpha \gamma \gamma \varepsilon \dot{\varepsilon} \lambda \lambda \varepsilon i v)$ is used to describe the activities of the Messiah (4:25) as well as the Paraclete (16:13, 14, 15). ${ }^{22}$ This verse in 1 John links God with Jesus as the light in the Gospel of John (Jn 1:4, 5; 8:1). In this way, the author wants to get it clear to his audience that what he writes stands in continuity with 'that which was from the beginning' (Thomas 2006:72) by Jesus and later the Paraclete.

The reference that 'God is light' $(1: 5)^{23}$ refers to the character of God. ${ }^{24}$ The author does not intend to define what God is in his nature (essence) but to provide a foundation for ethics. If God is light, then knowing God will imply to walk 'in the light' (1:7, cf. also 2:6; Kruse 2000:62). The focus is on God and the responsibility on the audience.

In the directly following verses (1:6-10), three conditional sentences are similarly introduced (v. 6: 'If we claim to have fellowship with him ...'; v. 8: 'If we claim to be without sin ...'; v. 10: 'If we claim we have not sinned ...') to reflect the author's understanding of the claims of the deceivers. In doing this, the author both addresses the false teaching of the deceivers and also reveals what he purports by saying that 'God is light; in him there is no darkness at all' (1:5; Kruse 2000:62).

Thus, both $\dot{\alpha} v \alpha \gamma \gamma \varepsilon \dot{\varepsilon} \lambda \lambda \varepsilon v v$ and $\dot{\alpha} \pi \alpha \gamma \gamma \varepsilon \dot{\varepsilon} \lambda \dot{\varepsilon} v$ relate to connect the author's proclamation with the reality of Jesus' existence and that the author finds himself within the tradition of the apostles (especially the author of the Gospel of John), Jesus and the Paraclete. This constitutes his proclamation to be true and reliable. The early Christians could have experienced this conviction to strengthen their faith in Jesus as the Son of God, experiencing both the resurrected Jesus and God when they live in the light.

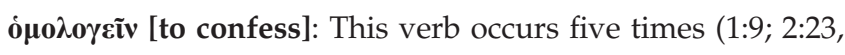
$4: 2,3,15)$ in 1 John (see figure 1 on next page). The one 20.Brown (1995:192-193) asserts that the author uses the phrase "the message equivalently to 'the gospel'.

21.For Painter (2002:125), Smalley (1989:19) and Kistemaker (19:241), the use of the plural 'we' may also refer to the tradition bearers, 'what we have heard from him'

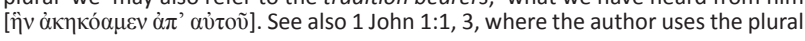

22.All three verbs are used in the future, indicative active mode: $\dot{\alpha} v \alpha \gamma \gamma \varepsilon \lambda \varepsilon \bar{\varepsilon}$. See also the proclamation of the man healed at the pool of Bethesda (John 5:15).

23.See Painter (2002:126) for an excellent discussion on the linguistic aspects of this verse.

24.Kruse (2000:62) refers to Dodd (1946:107-10) in his reference that both the OT and NT express the character of God in terms of God's actions, and not his nature. This then infers that the author's view differs from the pagan Greek view where the This then infers that the author's view differs from the pagan Greek view where the
opposite occurs. For them, the nature of God's being rather than his activities is the focal point. reference to 'confession' in 1:9 has to do with the forgiveness of sins. The other four references relate semantically closely to one another with regard to 'agreement' - to confess that Jesus has come in the flesh $(4: 2,3)$ and is the Son of God $(2: 23 ; 4: 15)$.

For Danker (2000), the verb refers:

to commit oneself to do someth[ing] for someone, promise, assure; to share a common view or be of common mind about a matter, agree; to concede that something is factual or true, grant, admit, confess; to acknowledge someth[ing], ordinarily in public, acknowledge, claim, profess, praise. (p. 708)

Zodhiates (2000:3670) defines it as, ' $[t]$ o be in accord with someone, to promise, followed by the dative and infinitive'. For Louw and Nida (1996:I, 708), this verb can be translated with, 'to acknowledge someth[ing], ordinarily in public, acknowledge, claim, profess, praise'. ${ }^{25}$ From these three lexicon

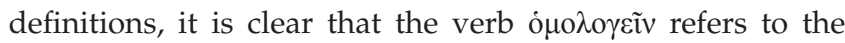
author sharing the message with the audience and against the 'deceivers' because of his agreement with others, from the tradition, that Jesus is the Son of God and came in the flesh.

Three of the five usages of the verb ó $\mu$ o polemical texts in 1 John, where the author uses it in conjunction with the opposite verb $\alpha \rho v \varepsilon i ̃ \sigma \theta \alpha 1$ [to deny]. By

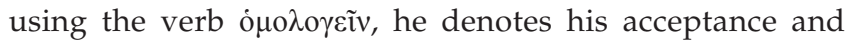
proclamation of a specific anti-heretical thesis, 'Who is the

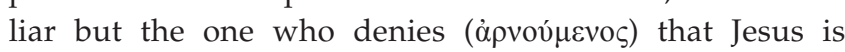
the Christ? This is the antichrist, the one who denies

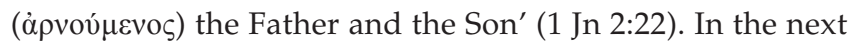

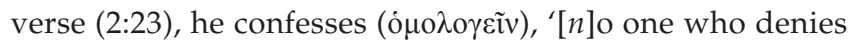
the Son has the Father; everyone who confesses the Son has the Father also'.

This didactic style defines and distinguishes afresh the terms

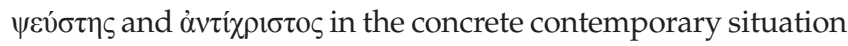
of the community. These arguments, moulded in the conflict with the deceivers, presuppose a specific confessional dialectic use of the two terms ó $\mu$ o verb ó $\mu$ 入 $о \gamma \varepsilon \tilde{v}$ expresses the acceptance of a specific Christological understanding, while $\alpha \rho v \varepsilon i \tilde{\sigma} \theta \alpha \mathrm{r}$ is the contesting of an acknowledged ecclesiastical truth. According to 1 John 4:2 f., the spirits must be tested to discover whether they are from God (cf. 1 Cor 12:3). Only the spirit that affirms the Christological truth that Jesus Christ has come in the flesh is from God. However, the spirit that does not confess Jesus ( $\pi \tilde{\alpha} v$

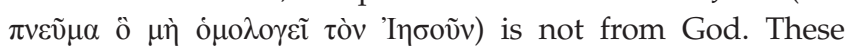
Johannine theses proclaim a solemn kerugmatic statement; they seek to express a specific truth, the only possible relation to Christ (Michel 1981:210).

1 John 4:15 shows that these kerygmatic statements are in no sense to be taken intellectually. Only those who confess that Jesus is the Son of God have true fellowship with God.

25. For Friberg et al. (2000:281), it can be translated to "say the same thing; (1) as binding a speaker to his word (solemnly) promise, assure (MT 14.7); (2) as confessing that something is true, admit, agree (HE 11.13); (3) in judicial matters make a binding statement, confess, bear witness (AC 24.14); as making a public make a binding statement, confess, bear witness (AC 24.14); as making a public
acknowledgment of allegiance confess, declare, acknowledge (JN 9.22). The acknowledgment of allegiance confess, declare, acknowledge (JN 9.22).
essence coming from these dictionaries is to share something in common'. 


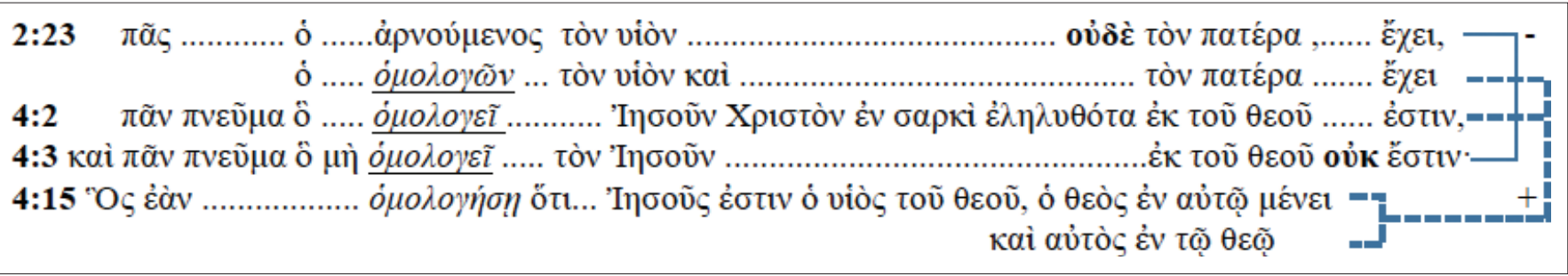

FIGURE 1: Analysis and comparison of the verb o $\mu \mathrm{o} \lambda \mathrm{o} \gamma \varepsilon \tilde{\mathrm{v} v}$.

In 1 John 2:22 the author defines both people and concepts in a fixed way. ${ }^{26}$ The author is not seeking to define a specific doctrine dogmatically. For him, a firm formulation of the kerygma overcomes the error of false teaching, in order to bring the opponents to decision and so to proclaim the old truth in a new situation so that its full saving significance is expressed and experienced. In the act of confession the whole truth is attested in individual confessional formulae. Though confession divides and distinguishes, it remains praise and acknowledgment of the identity of Christ. Confessions in the anti-heretical sense are new only in form. In substance, they are still concrete ecclesiastical truths unfolded in firm proclamation (Michel 1981:210).

Translated into English consistently as 'confession', the verb ó $\mu$ 入 $о \gamma \varepsilon \tilde{v}$ conveys basically the same meaning although used with slightly different nuances in different linguistic contexts, as follows. ${ }^{27}$ All the confessions in 1 John relate to confessing something about the identity of Jesus, as is evident from Figure 1.

The focus here is on the audience or receivers of the message: $\pi \tilde{\alpha} \varsigma$ [adjective] and ö $\varsigma$ [pronoun]. These confessions were vital, because of the dialectic circumstances in the community.

The audience know that according to the Gospel of John, a very close relationship and unity exist between the Father

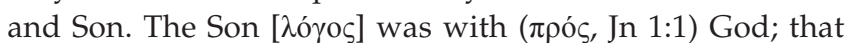
' $[t]$ he only begotten Son, who is in the bosom of the Father, He has declared Him' (1:18, NKJV); ${ }^{28}$ 'for whatever He [the Father] does, the Son also does in like manner' (5:23); that the one 'who does not honour the Son does not honour the Father' (5:23); 'I and My Father are one' (10:30); 'No one comes to the Father except through $\mathrm{Me}^{\prime}$ (14:6); 'If you had known Me, you would have known My Father also' (14:7); 'He who has seen Me (Jesus) has seen the Father' (14:9); 'He who hates Me hates My Father also' (15:23); and they are in one another (17:21-23). Therefore, the author could make the statement in 1 John 2:23 that a denial of the Son implies that that person is without the Father. From all these texts, the Son is identified with the Father; they are one. Therefore, it is suitable and striking that the author uses the verb

26.See 2 John 7 ff. (ovi. $\tau$ हैotiv ...). In a similar way, the author states in 2 john 7 that

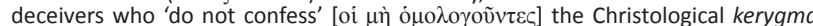
'have gone out into the world'. The concept ojo this context, then, carries disrupting power (Michel 1981:210).

27.Thomas (2006:202) points out that confession language occurs especially in Christological texts such as John 1:20; 9:22; 12:42; 2 John 2:23; 4:2, 3, 15; 2 John 7 .

28.The New Kings James Version (NKJV) gives a more literal and accurate translation and is used in all these quotations. o $\mu \mathrm{o} \lambda \mathrm{o}$ ¿ĩv to refer to his solidarity with Jesus' confession that the Father and Son are one.

The verb 'confess' is semantically related very closely to the following references in 1 John: 'having' [ع̈ $\chi \varepsilon v]$ ], 'abiding'

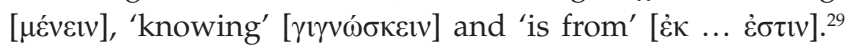
The texts in which these verbs occur convey 'the idea of a personal and intimate experiential relationship with God' (Thomas 2006:135). To confess Jesus is to identify oneself with him, accepting and experiencing the salvation constituted through his crucifixion and resurrection. The author then through repetition emphasises that a relationship with the Son is critically indispensable in order to have a relationship with the Father. Thus, an experience of the divine (the Father) is only possible through the Son. Through the Spirit, however, the Father also abides in believers (3:24; 4:13, cf. Thomas 2006:135-36).

In $4: 2$, the author informs the audience that their capability to know and to experience their mutual indwelling with God is only viable through the Spirit (cf. Kistemaker 2001:325). When the audience confess Jesus as the Christ who came in the flesh (Kistemaker 2001:325), they will then join the author in experiencing the divine through their confession of Jesus. The verb ó $\mu$ o 'denotes not mere verbal acknowledgment but an open and forthright declaration of the message as one's own position' (Akin 2001:172).

The Spirit generates the audience's confession as a result of a growing and experiential relationship with Jesus (Thomas 2006:203). The author's confession of Jesus is now familiar to the audience $(4: 2,3,15) \cdot{ }^{30}$ According to $3: 23$, the confessions of believers are no mere confirmations of doctrine. Rather, those who confess Jesus participate in the experiences of the Father made available by Jesus. To confess Jesus as the 'Son of God who was incarnated' is a summary statement that reflects the various dimensions of the work of Jesus. Hence, the testimony of 'lived experiences' through faith and the confession that Jesus is the Son of God confirms God's indwelling with the believer (also 4:15; cf. Thomas 2006:229).

- Through confessing (acknowledgement) Jesus as incarnated and one with God, the audience will join the author in experiencing the divine through his confession of Jesus.

29.These verbs can be termed as formulas of immanence (see Malatesta 1978:27; also Schnackenburg 1984:105-109).

30.See 2:23: 'No one who denies the Son has the Father; everyone who confesses the Son has the Father also'. 
- Confession constitutes experience. The more the audience confess Jesus, the more they will then experience him (his reality) as human as well as divine.

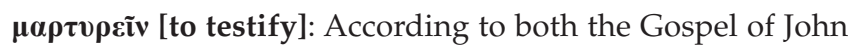
and 1 John, the theme of testimony seems to be prominent in the Johannine community. Of all the verbs used by the author, to refer to the communication of the message concerning Jesus Christ as the incarnated Son of God, the verb $\mu \alpha \rho \tau \nu \rho \varepsilon \tilde{v}$ has the highest frequency of occurrences in the letter - it occurs 10 times. ${ }^{31}$ For Danker (2000:617), this verb can be translated 'to confirm or attest someth $[i n g]$ on the basis of personal knowledge or belief, bear witness, be a witness; to confirm, bear witness to, declare, confirm'. Louw and Nida (1996:I, 417) define it as 'to provide information about a person or an event concerning which the speaker has direct knowledge - to witness'. Zodhiates (2000) declares this verb as:

a. [t]o be a witness, to be able or ready to testify, meaning in favour of whom or what one bears testimony (John 3:26; 5:33; 18:37)

b. [t]o bear witness, to testify to the truth of what one has seen, heard, or knows. (p. 3140)

These dictionaries are unanimous that the essence of $\mu \alpha \rho \tau$ seems to be 'to testify or witness about the truth one has seen, heard or knows'.

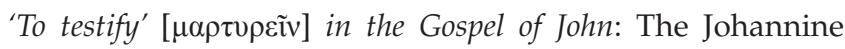

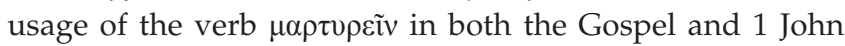
refers merely to the figure of Jesus as such, to his person and his significance (Strathmann 1978:IV, 497). ${ }^{32}$ The Gospel's usage distinctively portrays by the numerous passages the witness to Jesus. In the Gospel of John, many references about 'testimony' occur. The following references refer only to testifying about Jesus, his person and significance: The Baptist 'testifies about him' (Jn 1:15); the essence of the Baptist's witness is, 'I ... have testified that this is the Son of God' (1:34). In John 3:11 (also 15:27; 21:24), the discourse of Jesus became the preaching of the Evangelist. The works he was doing and the Father 'testify to $\mathrm{me}^{\prime}$ (5:31-39; cf. also 8:13-18; 10:25). 'When the Advocate comes, whom I will send to you from the Father, the Spirit of truth who comes from the Father, he will testify on my behalf' (15:26). The Evangelist's references concerning witness about the identity and significance of Jesus as a person had in mind the commencement to believe Jesus is the Messiah, the Son of God (20:31). Finally, in John 21:24 it is written, ' $[t]$ his is the disciple who is testifying to these things and has written them, and we know that his testimony is true ${ }^{\prime 33}$ (cf. Strathmann (1978:IV, 498; also Westcott 1902:45-48).

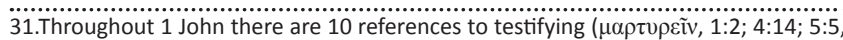
$7,9[3 x], 10[2 x], 11)$.

32.For Strathmann (1978:IV, 497) there are some texts where the verb occurs with no specific reference to Jesus (cf. 2:25; $3: 28 ; 4: 39,44 ; 12: 17 ; 13: 21 ; 18: 23$ ).

33.John 19:34-35: '.. one of the soldiers pierced his side with a spear, and at once blood and water came out. (He who saw this has testified so that you also may believe. His testimony is true, and he knows that he tells the truth)'.
This witness is not concerned with the factuality of Jesus' history, although this is assumed and even accentuated (Jn 15:27; 21:24; see also 3:11 and 1 Jn 1:2; 4:14); neither is it a witness regarding certain important events in the Jesus narrative, like his birth, death or resurrection. The witness is merely to 'the nature and significance of His person'34 (Strathmann 1978:IV, 498). It is a $\mu \alpha \rho \tau v \rho \varepsilon \tilde{v} \pi \varepsilon \rho \grave{~ \alpha u ̉ \tau o v ̃ ~(J n ~ 1: 15) ; ~}$

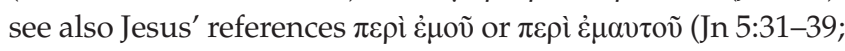
$8: 13-18 ; 10: 25 ; 15: 26)$. The content and quintessence of this

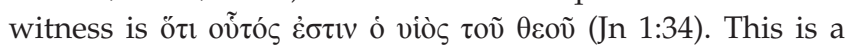
reference to his eternity (also cf. Jn 1:15). Jesus, numerously,

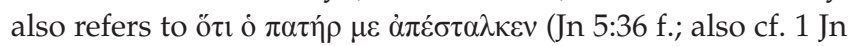
$4: 14) .{ }^{35} \mathrm{He}$ is the incarnate Word (Jn 1:14), for he came from heaven. When he talks about God he bears witness to what he has seen and heard from God (cf. 3:32; cf. also 3:11). He is the truth $(14: 6)$, and thus to bear witness to it $(5: 33 ; 18: 37)$ is to bear witness to him (3:26) or about himself (5:32). Testimonies about the aforementioned took place through the scriptures (5:39), through the Baptist (1:7f., 15, 32, 34; 3:26; 5:33), through God $(5: 32,37 ; 8: 18)$, through the works that the Father causes Jesus to do $(5: 36 ; 10: 25)$, and through Jesus himself.

After Jesus' return to the Father, the witness of the Spirit, who is the Spirit of truth (also referred to as 'the truth'; Jn $15: 26$; 1 Jn 5:6), bears witness to the Son of God as the One who gives eternal life (1 Jn 5:5-11). Finally, the witness given by the disciples themselves (Jn 15:27; cf. 1 Jn 4:14) is a confession (Strathmann 1978:IV, 498). Both the authors of John and 1 John declare to have been witnesses in the historical sense, eyewitnesses to the historical Jesus (Jn 1:14; 1 Jn 1:1-3; Strathmann 1978:IV, 497).

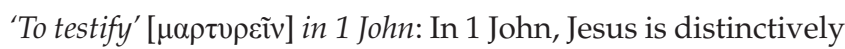
portrayed by a number of passages that speak about witness to Jesus. In 1 John, the author did not describe any factual history of Jesus nor certain significant events in his life, such as his birth, death or resurrection. Where the author uses the verb testify in 1 John, the entire life of Jesus is presupposed and even accentuated in order to portray his divine identity $(1: 2 ; 4: 14 ; 5: 5-12){ }^{36}$

Chapter 1: In 1:2, the author writes, 'And the life was revealed, and we have seen ( $\dot{\varepsilon} \omega \rho \dot{\alpha} \kappa \alpha \mu \varepsilon v)$ it and testify to it and declare to you the eternal life that was with the Father and was revealed to us'. In this verse, the author refers to 'the life'

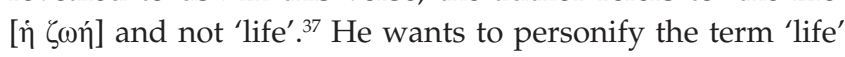

34.Trites (1978:1049) refers to three features that testimonies and witnesses in antiquity should have adhered to: (1) Witnesses are keenly involved in those things
and they endeavour to render. They cannot but speak to what they have experienced. (2) Witnesses are held accountable for the correctness of their testimonies. Perjury was regarded as a serious offence and heavily punishable. Four times Paul declares, 'God is my witness'. Preachers and Bible writers were driven back to the scriptures whereby their witness is to be judged. (3) The witnesses had to be trustworthy to both the bare facts of the Christ event and their meaning. This implies the presentation of Jesus as the Son of God, 'fully rounded, finely balanced, many sided yet unitary'.

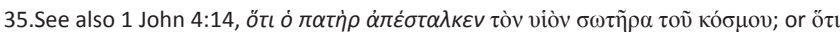

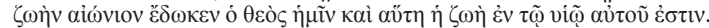

36.In John 19:35, the author states the objective of his testimony, 'that you also may believe'.

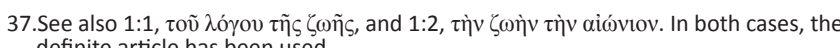
definite article has been used. 
(see also Jn 11:25; 14:6). ${ }^{38}$ Therefore, he places the definite

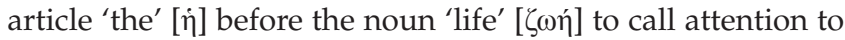
both the connection of 'the life' with the reference 'his Son Jesus Christ', in 1:3 and to the fullness of life in Jesus Christ (cf. Kistemaker \& Hendriksen 2001:236). He further defines this 'life' in 1:2 as 'the eternal life that was with the Father and was revealed to us'.

This verse certainly would have recalled among the audience ${ }^{39}$ both John 1:4 ('In Him was life, and the life was the light of men'; NKJV; also 5:19-29) to link it with the personification of life and John 1:14 ('And the Word became flesh and lived among us, and we have seen his glory'), to link it with the verb 'revealed', which occurs twice in 1 John 1:2. This reference and connection to Jesus as 'Life' could have recalled the words and content of 1 John $4: 9,10,14 .^{40}$

The author certainly claims to have been a witness in the historical sense, that is, an eyewitness to the historical Jesus (1 Jn 1:1-4) ${ }^{41}$ It is disclosed to and experienced only by the believer (1 Jn 5:9f.); nor is it disclosed merely to believers who were eyewitnesses in the historical sense but to all believers. ${ }^{42}$ Therefore, when the first audience read 1:1-3, they could have recalled and envisaged (reference to 'eyes', тoĩ ò $\varphi \alpha \lambda \mu$ oi $\varsigma, 1: 1)$ the entire life of Jesus as portrayed in the Gospel, namely, his baptism, discourses, miracles, crucifixion and resurrection (the author uses the verb $\dot{\varepsilon} \omega \rho \alpha \dot{\alpha} \alpha \mu \varepsilon v$ three times). The verbs 'revealed' (2x), 'have seen' (3x), 'have heard' $(2 x)$ and 'testify' relate closely and are experiential language and

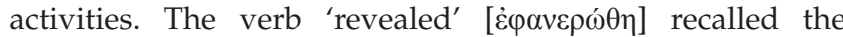
incarnation of the Son of God referred to in John 1:14. The literary context of the verb 'seen' also carries the meaning of physical sight and experience.

According to Thomas (2006:67), the author's testimony in 1:2 labels himself (the author) with those who faithfully identify themselves with Jesus and his accomplishments. The present tense in which the verb is used implies that the testimony of the author (and those in the tradition, $\mu \alpha \rho \tau$ in this context that their (plural) testimony, an ongoing activity, is still about Jesus (Thomas 2006:68). This testimony is based on what they have seen, heard and touched (1:1-4) and legitimises the truth of the testimony of the author.

Chapter 4: In 4:14 the author writes, '[a]nd we have seen [ $\tau \varepsilon \theta \varepsilon \alpha \dot{\alpha} \mu \varepsilon \theta \alpha]$ and do testify that the Father has sent his Son as the Savior of the world'. The core of this verse is equivalent to the previous verse $(1: 2)$ except that the verb $\tau \varepsilon \theta \varepsilon \alpha \dot{\alpha} \mu \varepsilon \theta \alpha$ 38.See also Dodd (1946:3-4), Smalley (1989:5), Schnackenburg (1984:59-60), Haas et al. (1994:14) and Akin (2001:54).

39.This audience would have been familiar with the Gospel of John, for they are part of this Johannine community.

40.4:9, 10, 14: 'God's love was revealed among us in this way: God sent his only Son into the world so that we might live through him. In this is love, not that we loved God but that he loved us and sent his Son to be the atoning sacrifice for our sins... And we have seen and do testify that the Father has sent his Son as the Savior of the world.'

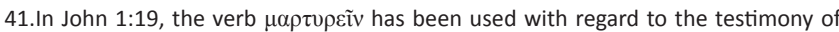
John the Baptist about Jesus.

42.For 'He who believes ( $\delta \pi \_\tau \varepsilon v ́ \omega v$ ) in the Son of God has the testimony in himself $(\dot{\varepsilon} \alpha v \tau \tilde{\omega})^{\prime}(5: 10)$ [we have seen] is used instead of $\dot{\varepsilon} \omega \rho \alpha ́ \kappa \alpha \mu \varepsilon v$. In this context, the verb 'seen' $[\tau \varepsilon \theta \varepsilon \alpha \dot{\alpha} \mu \varepsilon \theta \alpha]$ relates to interpretation and understanding: to perceive that Jesus is the Son, the Saviour of the world. The author's use of $\tau \varepsilon \theta \varepsilon \alpha \dot{\mu} \mu \theta \alpha \alpha$ is in his rhetoric a development to a higher level to guide the audience to understand, accept and experience God's love in sending 'his Son as the Savior of the world' (4:14). 'To testify', in this context, is the consequence and result of the author (or anyone) abiding in God and having received the Spirit (4:13).

In $4: 13$, the audience are reassured about their mutual indwelling with God. This is by means of the Spirit (5:14).

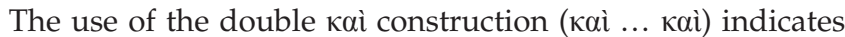

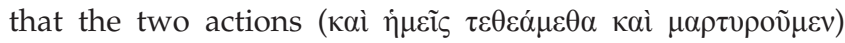
are connected and are closely related. According to this construction, the testimony then reads, 'we have seen or perceived and we testify'. This construction and the vocabulary used imply that a strong message is communicated to the audience (cf. Thomas 2006:227).

The recurrence of the verb 'see' $[\tau \varepsilon \theta \varepsilon \dot{\alpha} \mu \varepsilon \theta \alpha]$ recalls the previous occurrences ${ }^{43}$ of this verb in the Gospel of John (1:14; see his 'glory') $)^{44}$ and 1 John 1:1 (see him as the 'word of life') ${ }^{45}$ Even the reference to Jesus the Son as 'the Savior of the world' is also peculiar here. Kruse (2000:164) points out that

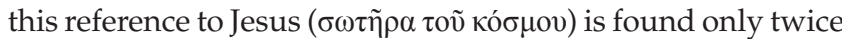
in the New Testament, here and in John 4:42. This would have intensified the imagination and experience of the audience. In this context then, to 'testify' emphasises the verb 'to see' [ $\tau \varepsilon \theta \varepsilon \alpha \dot{\alpha} \mu \varepsilon \theta \alpha]$, even though the author has stated in 4:12 that ' $[n]$ o one has ever seen God', but 'we' have now seen his Son as the Saviour and consequently 'seen' (experienced) the Father (Jn 14:9). It is possible that the 'visible' sight (on the part of eyewitnesses) and belief in the God who sent his Son converge into an integrated 'vision' and 'experience' of God's loving act of salvation (Thomas 2006:227).

The verb $\mu \alpha \rho \tau v \rho o v \tilde{\mu \varepsilon v}$ [we testify or witness] is used in the present tense and indicative mood to refer to an ongoing activity (cf. Smalley 1989:252). Therefore, the audience knew that witnessing is an ongoing activity in the community dealing with their relationship with the Father, which is enabled by the Spirit through Jesus. Thus, testifying is a result of the experiencing of God in the community. Through testimony, God is experienced by both the one who testifies and by those who hear it. In this context, then, the author indicates that his testimony (singular) is an ongoing activity about Jesus that is based on what he has seen. The reference to seeing legitimises the truth of the testimony of the author.

43.See Van der Merwe 2015:7, 8 and Waaijman (2002:744-746; also cf. Iser 1978:112 on the spiritualities fostered via the 'dialectic between retention and pretension' of texts.

44.Danker (2000:445) interprets $\tau \varepsilon \theta \varepsilon \alpha \dot{\mu} \mu \varepsilon \theta \alpha$ as 'to perceive someth [ing] above and beyond what is merely seen with the eye, see, behold, perceive'. Smalley's interpretation verifies and substantiates this. For him (1989:252), the 'sight' $[\tau \varepsilon \theta \varepsilon \alpha \dot{\alpha} \mu \varepsilon \theta \alpha]$ cannot be taken literally. The reason is that the object in the [ $\varepsilon \theta \varepsilon \alpha \mu \varepsilon \theta \alpha]$ cannot be taken literally. The reason is that the object in the subordinating ó $\tau$ [that] clause ('the Father has sent the Son as saviour of the world') is not observable with the eyes (cf. also Bultmann, 1973:71). This sigh is primarily a 'seeing of faith' (cf. 4:16). For Beasley-Murray (2002:14), the verb $\tau \varepsilon \theta \varepsilon \alpha \mu \varepsilon \theta \alpha$ 'connotes more than contemporary spiritual insight of faith, though it
doubtless includes it'.

45.In 1:1, the author uses the aorist $(\dot{\varepsilon} \theta \varepsilon \alpha \sigma \alpha \dot{\alpha} \mu \varepsilon \theta \alpha)$ and in 4:14 the perfect $(\tau \varepsilon \theta \varepsilon \alpha \dot{\mu} \mu \varepsilon \theta \alpha)$. 


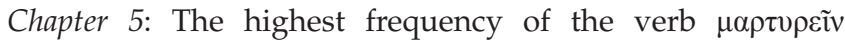
$(5: 6,7,9,10)$ and noun $\mu \alpha \rho \tau v \rho i ́ \alpha ~(5: 8,9$ [bis], 10 [bis], 11) occurs in Chapter 5 . One reference refers to the testimony of people (5:9). There is reference to the testimony of 'water', 'blood' and the Spirit. The rest (six occurrences) refer to the testimony of God. Twice the author refers to the 'witness of God'

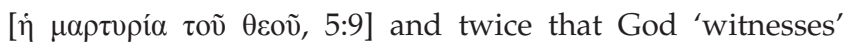
[ $\mu \varepsilon \mu \alpha \rho \tau \dot{\rho} \rho \eta \kappa \varepsilon v]$.

The author refers firstly to the Spirit in the list of witnesses (5:6). Strathmann $(1978: I V, 500)$ argues that according to the context, this witness of the Spirit resonates with the witness of God, referred to in 5:9-11. The idiosyncratic phrase in 5:10a ('He who believes in the Son of God has the testimony in himself') shows that this witness of the Spirit is the testimonium spiritus sancti internum (Strathmann 1978:IV, $500)$, in virtue of which mankind may be sure of the content of the divine $\mu \alpha \rho \tau v \rho i ́ \alpha$.

In 5:7-8, the author adds two more witnesses who witness with the Spirit: the water and blood. Reference to the testimony of the 'Spirit' is mentioned first because the Spirit testifies through the water and blood (as in 5:6; see Smalley 1989:281). ${ }^{46}$ A number of scholars are unanimous ${ }^{47}$ that the explicit reference of witness of the water and blood denotes the historical events surrounding the humanity and ministry of Jesus and the salvific character of Jesus (cf. Smalley 1989:280). It signifies the public life of Jesus, starting with his baptism (water) until his crucifixion (blood). The Spirit who descended on Jesus at his baptism (Jn 1:32) was a witness to the water and blood. Jesus gave this Spirit also to his disciples after his resurrection (Jn 20:22; cf. 7:39) to empower them for their mission (Jn 20:22; cf. 15:26-27; Smalley 1989:282). The audience knew this because already in John 15:26 Jesus said, 'When the Advocate comes, whom I will send to you from the Father, the Spirit of truth who comes from the Father, he will testify on my behalf'. This similarity would not be missed by the audience. Believers continuously have fresh experiences of the Spirit, especially in their participation in the sacraments. The testimonies (witness) of the divine and the 'water and blood' are necessary to confirm that the author's testimony is true and that God is involved in the mission of Jesus.

The lived experience of Jesus as the Son of God by the believers is further strengthened and fostered by the clause, 'has the

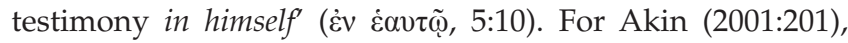
this clause suggests that the author is referring here 'to the inner testimony of the Spirit in the heart of the believer'.

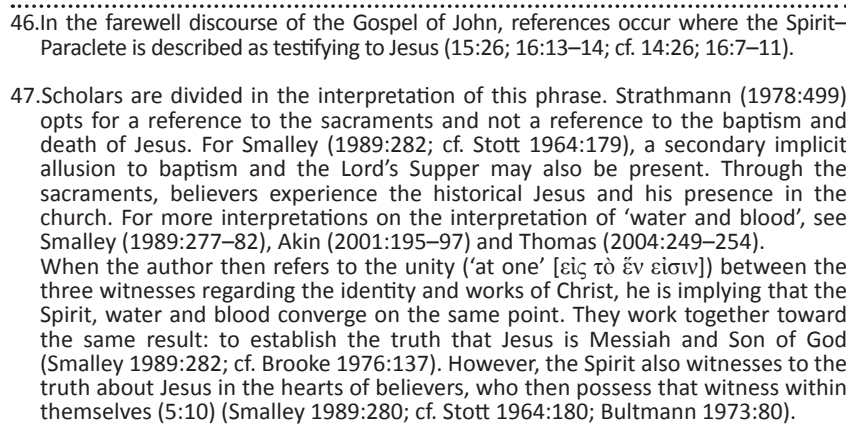

47.Scholars are divided in the interpretation of this phrase. Strathmann (1978:499) opts for a reference to the sacraments and not a reference to the baptism and death of Jesus. For Smalley (1989:282; cf. Stott 1964:179), a secondary implicit allusion to baptism and the Lord's Supper may also be present. Through the sacraments, believers experience the historical Jesus and his presence in the church. For more interpretations on the interpretation of 'water and blood', see Smalley (1989:277-82), Akin (2001:195-97) and Thomas (2004:249-254). Smalley (1989:277-82), Akin (2001:195-97) and Thomas (2004:249-254).

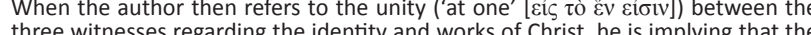
three witnesses regarding the identity and works of Christ, he is implying that the Spirit, water and blood converge on the same point. They work together toward the same result: to establish the truth that Jesus is Messiah and Son of God (Smalley 1989:282; cf. Brooke 1976:137). However, the Spirit also witnesses to the truth about Jesus in the hearts of believers, who then possess that witness withi themselves (5:10) (Smalley 1989:280; cf. Stott 1964:180; Bultmann 1973:80).

Smalley (1989:285-286) asserts that the internal witness of the Spirit of God shows believers that 'this "internal testimony" (of the Spirit) balances and complements the external and historical witness of the "water and blood", the baptism and death of Jesus'.

In 5:9, the author introduces the 'testimony of God'. The testimony concept in 1 John culminates in this paragraph. As already pointed out, twice the author refers to God's testimony and twice that God testifies. From 5:11, the author gives content to the 'witness of God'. He introduces the verse

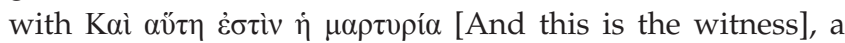
formula familiar to the audience. Thus, both the authority and approval of God have labelled the truth of the message concerning Jesus Christ (Akin 2001:200). This formula points to the clause 'that God gave us eternal life'. Thus, God who 'testifies' is the one who gave 'eternal life' (Thomas 2006:260). In the prologue of 1 John, the author refers to Jesus as 'that eternal life' (1:2). He ends 1 John by describing eternal life as knowing Jesus, who is true, and being in him who is true (5:20). The believer's experience of living in the light (truth) a life of love and righteousness reveals divine characteristics, as well as of eternal life, and subsequently proves that Jesus is the Christ, the Son of God.

Here the author uses 'eternal life' analogously to how Jesus uses it in John 17:3: 'And this is eternal life, that they may know ( $\gamma ı \omega \omega \sigma \kappa \omega \sigma ı v)$ you, the only true God, and Jesus Christ whom you have sent'. This refers to a quality of life emanating from having true fellowship with God and his Son, who are both light, righteous, truth and love. This starts with a person's conversion from 'death' to 'life' (cf. 1 Jn 3:14-15). It involves knowing $\operatorname{God}^{48}$ and Jesus, where the verb 'knowing' involves a close, personal and intimate experiential relationship with the divine (cf. Thomas 2006:262; Strecker 1996:195). For Köstenberger (2004:488) 'to know' God does not denote cognitive knowledge (the Greek perception); it rather denotes living in fellowship with God. Through fellowship with God, God becomes known. This implies a certain quality of life (cf. Smalley 1989:287). These early Christians experienced God's testimony regarding Jesus as the Son of God when they loved one another, lived in the light and lived in righteousness.

This section also, as the previous two (1:2; 4:14), emphasises the continuity of witnessing. The present participle mood of the verb (present active indicative in 1:2 and 4:14) indicates that the witness of these three is an ongoing and continuous event. It is still happening. It is in accord with the Fourth Gospel, 'where the act of believing is grounded on the witness or testimony of others' (Thomas 2004:254). The object is also Jesus. The difference between this text and the other two ( $1 \mathrm{Jn}$ $1: 2 ; 4: 14)$ is that here the subject of testifying is different. God, the Spirit and the water and blood are testifying, and not the author. The high frequency of 'testifying' in this pericope verifies that continuous testimonies validate more and more

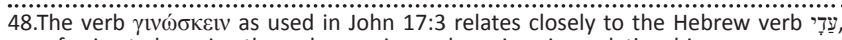
referring to knowing through experience, knowing via a relationship. 
the reality, truth and assurance of the content of these testimonies. For those who persevere in testifying, the more the content becomes real and experiential, as was the case with the author. The testimony of the author culminates in 5:13: 'I write these things to you who believe in the name of the Son of God, so that you may know [experience] that you have eternal life'.

\section{Conclusion}

This research pointed out how the author of 1 John decisively utilised four different verbs, 'declaring', 'proclaiming', 'confessing' and 'testifying', to emphasise and to convince his audience from different perspectives and probably also to foster different lived experiences, to believe that Jesus is the incarnated Son of God. Analogous to this modus operandi the author simultaneously opposed the deceivers who had a disturbed view of his confession regarding the identity and character of Jesus. I am convinced that the author purposefully used these four verbs to foster certain lived experiences (affects) to achieve this objective (effect) - to believe him and not the deceivers that Jesus is the incarnated Son of God. 1 John 5:13 summarises this: "These things I have written to you who believe in the name of the Son of God, that [iv $\alpha$ ] you may know that you have eternal life, and that you may continue to believe in the name of the Son of God'.

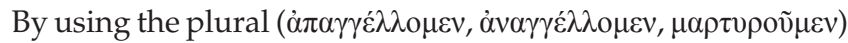
in Chapter 1 the author introduces himself to be in line with the message of the tradition. When he twice uses the verb

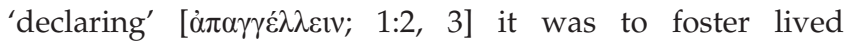
experiences of the entire ministry of Jesus, the reality of the existence of the Son of God incarnated as Jesus. Then, the

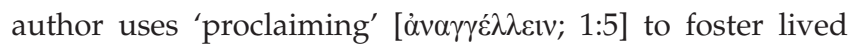
experiences of the truthfulness of God, who is said to be 'light'. He connects God with Jesus, who is also portrayed in the Gospel of John as light. The proclamation of the author fosters a lived experience of the unity between God and Jesus Christ his Son $(1: 5,7)$. This is crucial for the forgiveness of $\sin$

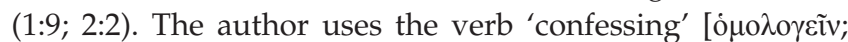
$1: 9 ; 2: 23,4: 2,3,15]$ only in the singular. Except for its use in 1 John $1: 9$ the verb occurs in heretical contexts, where this verb should foster lived experiences, where the audience upon hearing this message is put to a test of choice. If they accept the author's confession about Jesus they will experience God abiding in them, and they in God (4:15). Finally, when the author made use of the verb 'testifying' [ $\mu \alpha \rho \tau \nu \rho \varepsilon \tilde{v}, 1: 2 ; 4: 14$; 5:6-11], his usage of it in 5:6-11 is to verify his usage of this verb in 1:2 and 4:14. In 1:2 he refers to the physical ministry of Jesus and in 4:14 he has interpreted it and now testifies that 'the Father has sent the Son as Savior of the world'. In 5:6-11 the author associates his testimony with divine testimony to verify the trustworthiness of his testimony. The audience again experience divine involvement in these events.

This explained rhetoric chosen by the author in the manner in which he uses language created a dynamic interaction between the text and the audience. His specific and intentional use of different verbs for communicating the message fosters meaning and 'lived experiences' into coherent thoughts and ideas. These thoughts and ideas are then recreated in the minds of the audience, such that the ultimate goal is the embodiment of the words as they become 'lived experiences' of the divine that could transform their lives.

\section{Acknowledgements}

The author thanks Proff. Celia Kourie and Pieter de Villiers for they have steered (and influenced) the discipline of Christian Spirituality in South Africa in an interesting and exciting way. The grant received from the National Research Foundation during 2017 was used to fund the attendance of the International meeting of the Society of Biblical Literature in Berlin 2017 where this essay was presented as a paper. Funding for this study was provided by the North-West University.

\section{Competing interests}

The author declares that he has no financial or personal relationships that may have inappropriately influenced him in writing this article.

\section{References}

Akin, D.L., 2001, 1, 2, 3 John, Broadman \& Holman Publishers, Nashville, TN.

Almond, P.C., 1982, Mystical experience and religious doctrine: An investigation of the study of mysticism in world religions, Mouton, Berlin.

Batluck, M., 2011, 'Religious experience in New Testament research', Currents in Biblical Research 9(3), 339-363.

Beasley-Murray, G.R., 2002, John, Word Incorporated, Dallas, TX.

Brooke, A.E., 1976[1912], A critical and exegetical commentary on the Johannine epistles, T. \& T. Clark, Edinburgh.

Brown, R.E., 1995, The Epistles of John, Yale University Press, New Haven, CT.

Bultmann, R., 1973, The Johannine epistles, Fortress, Philadelphia, PA. (Herder).

Byrskog, S., 2009, 'When eyewitness testimony and oral tradition become written text', Svensk exegetisk årsbok 74, 41-53.

Clark, W.H., Malony, H.N., Daane, J. \& Tippett, A.R., 1973, Religious experience: Its nature and function in the human psyche, C.C. Thomas, Springfield.

Craffert, P.F., 2008, The life of a Galilean Shaman. Jesus of Nazareth in anthropological historical perspective, Cascade Books, Eugene.

Czachesz, I., 2015, Religious experience in mediterranean antiquity: Introduction', JCH 2(1), 5-13.

Danker, F.W. (ed.), 2000, Greek-English lexicon of the New Testament and other early Christian literature, 3rd edn., University of Chicago Press, Chicago, IL. (W. Bauer, F.W. Danker, W.F. Arndt and F.W. Gingrich, BDAG).

Dodd, C.H., 1946, The Johannine Epistles, Hodder and Stoughton, London.

Dole, A., 2016, 'What is 'religious experience' in Schleiermacher's Dogmatics, and why does it matter?', Journal of Analytic Theology 4, 44-65.

Dunn, J.D.G., 1970, Baptism in the Holy Spirit, SCM, London.

Dunn, J.D.G., 1997[1975], Jesus and the Spirit, Eerdmans, Grand Rapids, MI.

Fee, G.D., 1994, God's Empowering Presence: The Holy Spirit in the Letters of Paul, Hendrickson Publishers, Peabody, MA.

Filson, F.V., 1969, 'First John: Purpose and message', Interpretation 23(3), 259-276. https://doi.org/10.1177/002096436902300301

Flannery, F., Shantz, C. \& Werline, R.A., 2008, Inquiry into religious experience in early Judaism and experientia, vol. 1, Society of Biblical Literature, Atlanta, GA.

Friberg, T., Friberg, B. \& Miller, N.F., 2000, 'Tic' [someone], in Analytical lexicon of the Greek New Testament, vol. 4, p. 381, Baker Books, Grand Rapids, MI. (Baker's Greek New Testament library).

Gunkel, H., 1979[1888], The Influence of the Holy Spirit, transl. R.A. Harrisville \& P.A. Quanbeck, Fortress Press, Philadelphia, PA.

Haas, C., De Jonge, M. \& Swellengrebel, J.L., 1994, A Handbook on the letters of John, United Bible Societies, New York.

Hurtado, L.W., 2000, 'Religious experience and religious innovation in the New Testament', The Journal of Religion 80(2), 183-205. https://doi.org/10.1086/490606

Hurtado, L.W., 2003, Lord Jesus Christ: Devotion to Jesus in early Christianity, Eerdmans, Grand Rapids, MI. 
Iser, W., 1978, The act of reading: A theory of aesthetic response, Johns Hopkins University Press, Baltimore, MD.

Jantzen, G.M., 1989, 'Mysticism and experience', Religious Studies 25(3), 295-315. https://doi.org/10.1017/S0034412500019867

Johnson, L.T., 1998, Religious experience in early Christianity, Ress Press, Minneapolis, MN

Johnson, T.F., 1993, 1, 2, and 3 John, Hendrickson Publishers, Peabody, MA.

Kistemaker, S.J. \& Hendriksen, W., 2001, Exposition of James and the Epistles of John, Baker Book House, Grand Rapids, MI.

Köstenberger, A.J., 2004, John, Baker Academic, Grand Rapids, MI.

Köstenberger, A.J., 2011, Invitation to biblical interpretation: Exploring the hermeneutical triad of history, literature, and theology, Kregel Publications, Grand Rapids, MI.

Kruse, C.G., 2000, The letters of John, The Pillar New Testament Commentary, Apollos, Leicester.

Lieu, J., 1997, The theology of the Johannine epistles, Cambridge University Press, Cambridge.

Louw, J.P. \& Nida, E.A., 1996, Greek-English lexicon of the New Testament based on semantic domains, vol. 1, 2nd edn., United Bible Societies, New York.

Malatesta, E., 1978, Interiority and covenant, Biblical Institute Press, Rome.

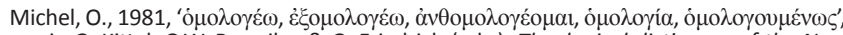
in G. Kittel, G.W. Bromiley \& G. Friedrich (eds.), Theological dictionary of the New Testament, vol. 5, pp. 199-220, Eerdmans, Grand Rapids, MI.

Painter, J., 2002, 1, 2, and 3 John, The Liturgical Press, Collegeville.

Pilch, J.J., 1996, 'Altered states of consciousness: A "Kitbashed" model', Biblical Theology Bulletin 26, 133-38.

Pilch, J.J., 2011, Flights of the Soul: Visions, heavenly journeys, and peak experiences in the Biblical World, Eerdmans, Grand Rapids, MI, viewed 14 March 2017, from http:// www.ttb.org/ docs/dePark fault-source/Booklets/when-paul-prayed.pdf?sfvrsn=2

Räisänen, H., 1999, 'Tradition, experience, interpretation: A dialectical model for describing the development of religious thought', in T. Ahlbäck (ed.), Approaching religion, pp. 215-26, Almqvist \& Wiksell International, Stockholm.

Räisänen, H., 2000, Beyond New Testament theology: A story and a programme, 2nd edn., SCM Press, London.

Schleiermacher, F. 1979[1830], The Christian faith, transl. H.R. Mackintosh \& J.S Stewart, Biddies Ltd, King's Lynn, Norfolk.

Schnackenburg, R., 1984, Die Johannesbriefe, Herder, Freiburg.

Schneiders, S.M., 2000, 'Spirituality in the academy', in K.J. Collins (ed.), Exploring Christian spirituality. An ecumenical audience, pp. 249-269, Baker Books, Grand Rapids, MI.

Shantz, C. \& Werline, R.A., 2012, Linking text and experience, Experientia, vol. 2 Society of Biblical Literature, Atlanta, GA

Smalley, S.S., 1989, 1, 2, and 3 John, Word Incorporated, Dallas, TX.
Stark, R., 1965, 'A taxonomy of religious experience', Journal for the Scientific Study of Religion 5, 97-116.

Stott, J.R.W., 1964, The epistles of John: An introduction and commentary, Inter-Varsity Press, Leicester (Tyndale New Testament Commentaries).

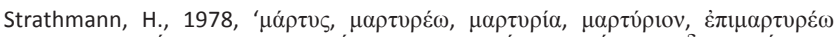

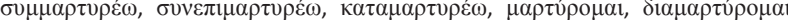

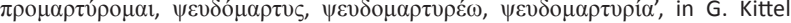
G.W. Bromiley \& G. Friedrich (eds.), Theological dictionary of the New Testament, vol. IV, pp. 497-499, Eerdmans, Grand Rapids, MI.

Strecker, G., 1996, The Johannine letters: A commentary on 1, 2, and 3 John, Fortress Press, Minneapolis, MN.

Theissen, G., 2007, Erleben und Verhalten der ersten Christen: Eine Psychologie des Urchristentums, Guitersloher Verlagshaus, Guitersloh.

Theissen, G., 2013, 'Paulus und die Mystik: Der eine und einzige Gott und die Transformation des Menschen', Zeitschrift Für Theologie Und Kirche 110(3), 263-90, https://doi.org/10.1628/004435413X666341

Thomas, J.C., 2004, A Pentecostal commentary on 1 John, 2 John, 3 John, The Pilgrim Press, Cleveland, $\mathrm{OH}$

Thomas J.C., 2006, The pentecostal commentaryon 1 John, 2 John, 3 John., The Pilgrim Press, Cleveland, $\mathrm{OH}$

Trites, A.A., 1978, 'Witness, testimony', in C. Brown (ed.), Dictionary of New Testament theology, vol. 3, pp. 1047-1050, The Paternoster Press, Exeter.

Van der Merwe, D.G., 2005, 'The soteriology of the Johannine Epistles', in J.G. van der Watt (ed.), The soteriology of the New Testament, pp. 437-464, Brill, Leiden.

Van der Merwe, D.G., 2009, 'Animosity in the Johannine Epistles', in J.T. Fitzgerald, F.J. van Rensburg \& H.F. van Rooy (eds.), Animosity, the Bible, and us, pp. 231-262 Society of Biblical Literature, Atlanta, GA.

Van der Merwe, D.G., 2015, '1 John: "Effects" in biblical texts that constitute "lived experiences" in the contemplative reading of those texts', In die Skriflig 49(2), 1-9. https://doi.org/10.4102/ids.v49i2.1930

Van der Merwe, D.G., 2017 “"Lived experiences” of the love of God according to 1 John 4: A spirituality of love', In die Skriflig 51(3), 1-8.

Van der Merwe, D.G., 2018, 'The author of 1 John uses the multiple references to his "writing" as a mechanism to establish affects and effects', HTS Theological Studies 74(3), 1-9.

Waaijman, K., 2002, Spirituality: Forms, foundations, methods, transl. J. Vriend, Peeters, Dudley.

Westcott, B.F. (ed.), 1902, The Epistles of St. John: The Greek text with notes and essays, 4th edn., Macmillan, London.

Yonge, C.D., 1995, The works of Philo: Complete and unabridged, Hendrickson, Peabody, MA.

Zodhiates, S., 2000, The complete word study dictionary: New Testament, AMG Publishers, Chattanooga, TN. 